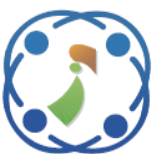

INASS
International Journal of

Intelligent Engineering \& Systems

http://www.inass.org/

\title{
Enhancement of Photovoltaic Pressurized Irrigation System Based on Hybrid Kalman Fuzzy
}

\author{
Suwito Suwito \\ Mochamad Ashari ${ }^{1 *}$ \\ Muhammad Rivai ${ }^{1}$ \\ M. Anis Mustaghfirin ${ }^{2}$ \\ ${ }^{I}$ Department of Electrical Engineering, Institut Teknologi Sepuluh Nopember, Indonesia \\ ${ }^{2}$ Department of Marine Engineering, Politeknik Perkapalan Negeri Surabaya, Indonesia \\ * Corresponding author's Email: ashari@ee.its.ac.id
}

\begin{abstract}
This paper presents an enhancement of a pressurized irrigation system without battery and water tank storage The system is powered by a photovoltaic (PV) system with a hybrid Kalman filter and fuzzy logic (HKF)-based control system. The Kalman filter estimates the maximum power point, whereas fuzzy logic controls the boost converter to optimize the PV output. The system manages the water pressure by matching the power of the brushless DC (BLDC) motor and the number of valves to be operated. A prototype of the system was built on a laboratory scale using a 32bit ARM microcontroller and pressurized irrigation networks. Results from the simulation and prototype tests were very similar in terms of tracking the optimum power. The average steady-state oscillation amplitude is 0.65 watts, while the average rise time is 1.02 seconds. The performance of the HKF is much better than perturb and observe (P\&O) method.
\end{abstract}

Keywords: Fuzzy logic, Pressurized irrigation, Kalman filter, Microcontroller, Maximum power point tracking, Photovoltaic.

\section{Introduction}

The utilization of PV panels as a source of energy for irrigation in remote agricultural land is gaining popularity $[1,2]$. Increasingly expensive national electricity prices and cheaper PV panel prices encourage PV as an energy source in the agricultural irrigation sector [3-5]. The solar photovoltaic pressurized irrigation system (SPVPIS) is the most efficient type of irrigation for electricity and water consumption. This irrigation system distributes water from the underground tank, pumped directly through the irrigation pipe network to the plants with slight discharge and volume according to the plant's needs. The consistent emitter discharge, which is impacted by the irrigation operating pressure (IOP), is one of the effective variables in ensuring the intended performance of the pressurized irrigation system [6].

SPVPIS without energy storage is preferred because it is cheaper, and there are no investment or maintenance costs for the energy storage [7, 8]. Although SPVPIS is the most efficient, it is susceptible to solar irradiation because it must be used simultaneously when generated [7]. Therefore, the success of this system depends on the controller's ability to optimize and instantly manage the available PV energy to meet the demand. Maximum power point tracking (MPPT) is the most efficient way to optimize PV energy. The basic principle of MPPT is to adjust the PV load impedance until the maximum power point (MPP) is obtained $[9,10]$.

Many researchers have studied the optimization of PV-powered irrigation systems. Several researchers developed the MPPT method without using a DC converter but by controlling the speed of a BLDC motor-driven pump. The technique they developed aims to reduce the cost and energy loss due to the DC converter [11]. Although the power losses can be reduced, direct MPPT control through the BLDC motor drive inverter causes the MPPT response to be slow and produces quite large oscillations in the MPP. Other researchers have developed MPPT using Cuk [12], Landsman [13], and Zeta DC converters which are controlled by the 


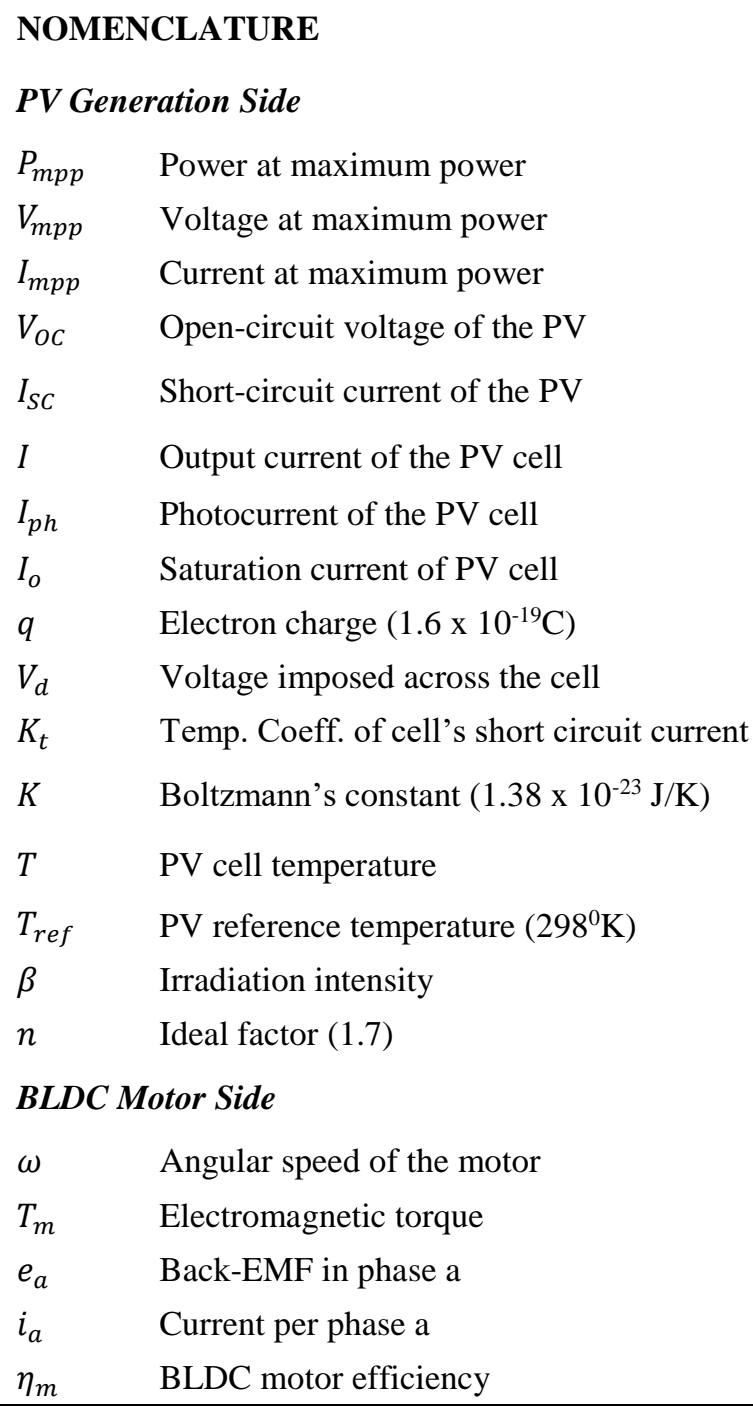

incremental conductance (INC) method [14]. The disadvantage of conventional INC control in these studies is the relatively large oscillation in the MPP. Some researchers apply fuzzy logic controller (FLC) to photovoltaic water pump systems with a fixed hydraulic load, namely lifting water to a reservoir at a fixed height [15]. The method still has significant oscillations during the transition which causes the pump speed to oscillate. Research related to irrigation management based on sensors of soil moisture, temperature, and light intensity that is processed using FLC is able to control irrigation capacity very accurately [16]. However, because PV panels have not been used as an energy source, this method is difficult to implement in remote areas. The division of irrigation areas into several sectors, or called multi-sector, has succeeded in reducing the cost of PV generation and increasing energy efficiency $[7,17$, 18]. However, the study did not pay attention to the optimization of PV output power and did not consider the irrigation dose error due to changes in IOP.

\section{Boost Converter Side}

$V_{\text {in }} \quad$ Input voltage on the boost converter.

$V_{\text {out }} \quad$ Output voltage on the boost converter.

$D \quad$ Duty cycle of boost converter

$f_{\text {sw }} \quad$ Switching frequency of the converter

\section{Pressurized Irrigation Side}

$P_{w h p} \quad$ Water horsepower

$\rho \quad$ Density of water $(1000 \mathrm{~kg} / \mathrm{m} 3)$

$g \quad$ Gravitational constant $\left(9.8 \mathrm{~m} / \mathrm{s}^{2}\right)$

$H_{p} \quad$ Total pump head

$Q_{p} \quad$ Pump discharge

$\eta_{p} \quad$ Water pump efficiency

\section{Hybrid Kalman-Fuzzy Method Side}

$\widehat{V}_{k}^{-} \quad$ Predicted Vmpp in $\mathrm{k}^{\text {th }}$ iterations

$P_{k}^{-} \quad$ Priori error covariance in $\mathrm{k}^{\text {th }}$ iterations

$K_{k} \quad$ Kalman gain in $\mathrm{k}^{\text {th }}$ iterations

$\widehat{V}_{k} \quad$ Updated estimate of the Vmpp in $\mathrm{k}^{\text {th }}$ iterations

$P_{k} \quad$ Update error covariance in $\mathrm{k}^{\text {th }}$ iterations

$Q \quad$ Process noise covariance

$R \quad$ Measurement noise covariance

$M \quad$ Scaling factor

$P_{p v, k} \quad$ PV output voltage at $\mathrm{k}^{\text {th }}$ iterations

$V_{p v, k} \quad$ PV output power at $\mathrm{k}^{\text {th }}$ iterations

Studies related to MPPT that are applied to the solar photovoltaic water pump (SPVWP) still have problems, namely relatively slow response and power oscillations in MPP. If the system is used in SPVPIS, it will result in fluctuating IOP which will eventually lead to inaccurate water dosing. The unsynchronization between the availability of PV output power and irrigation capacity worsens the stability of the IOP.

The main objective of the proposed system is to increase the optimization of SPVPIS using MPPT, which is synchronized with the irrigation sector controller. The novelty of this research is MPPT control using Kalman filter, and (FLC called hybrid Kalman fuzzy (HKF). Compared to the FLC method in other studies, this proposed method has a faster transient response and has lower power oscillations at MPP. The Kalman filter estimates the MPP voltage while the FLC controls the DC converter to achieve MPP based on the error voltage between the MPP voltage estimate and the actual PV voltage. The 


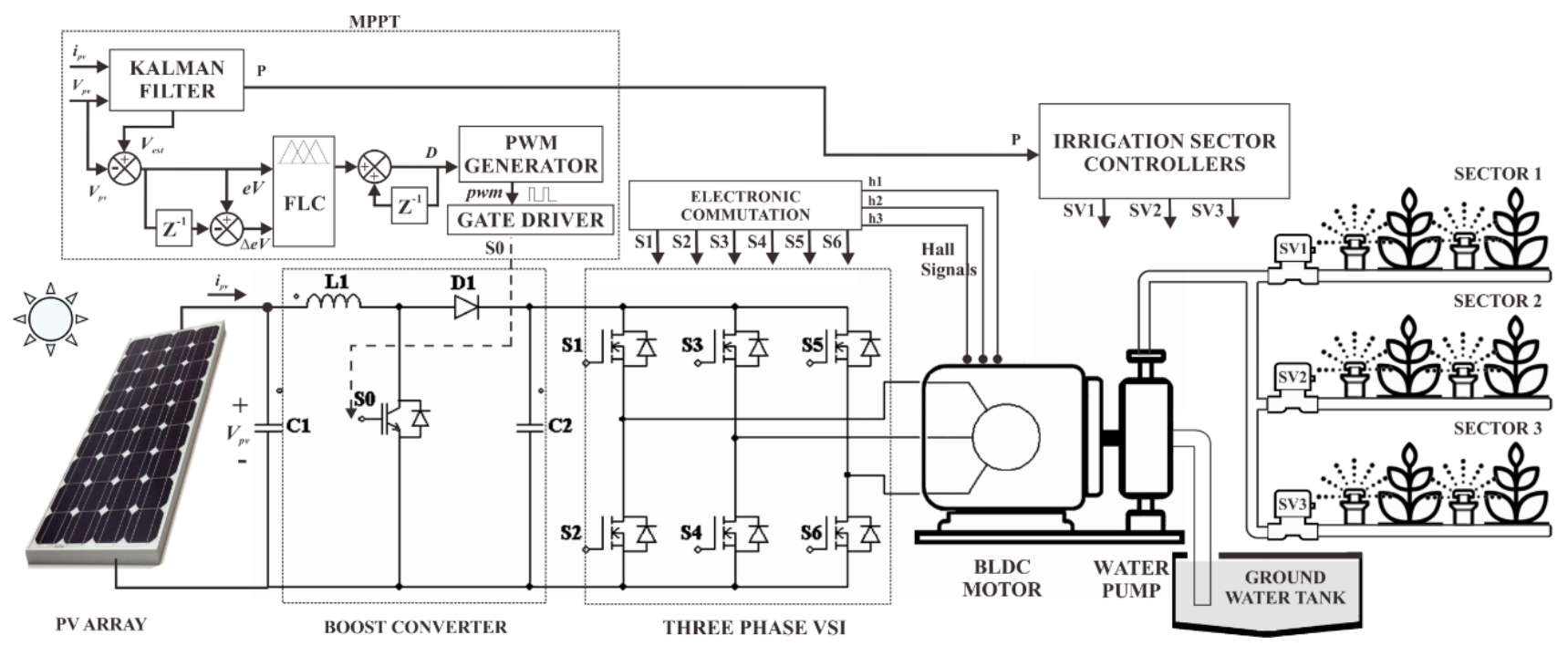

Figure. 1 The functional diagram of the proposed system

method offered has an accurate and fast MPP tracking performance and has a low steady-state oscillation. The Kalman filter has efficient computation and supports the estimation of the present, past, and future states $[19,20]$. This filter can also estimate when the system's character being modeled is unknown. Efficient computing makes the Kalman filter easy to implement on a microcontroller. Fuzzy logic resembles humans and can be adapted to nonlinear control commands [21]. Fuzzy logic is also very effective in dealing with complex processes, and the mathematical model is unknown [22]. This HKFbased MPPT method has been applied to the SPVPIS prototype. The system built is simulated on MATLAB/SIMULINK and verified through experiments with hardware.

This paper is structured as follows: Section 2 describes our proposed system. A detailed discussion of the optimization and control methods is discussed in Section 3. The simulation and experimental preparation, and test results are discussed in Section 4. Section 5 presents the conclusions of this paper.

\section{The proposed system}

A functional diagram of the proposed system is presented in Fig. 1. The system consists of several subsystems: a PV array, a boost converter with fuzzy logic as an MPPT controller, inverter-BLDC motor, water pump set, and pressurized irrigation network with the Kalman filter controller. This system focuses on optimizing the PV output using the MPPT based on the HKF method. The PV output power is optimally used by adjusting the irrigation capacity according to the output power.

\subsection{PV characteristics}

The PV panels are a series and parallel combination of PV cells having the equivalent circuit shown in Fig. 2. The photovoltaic current is affected by solar irradiation and the temperature of the PV panel according to Eq. (1). The shunt resistance $\left(R_{s h}\right)$ is typically much greater than the load resistance, whereas the series resistance $\left(R_{S}\right)$ is much less. As a result of omitting these two resistances, the cell output current can be expressed as Eq. (2) [23, 24].

$$
I_{p h}=\left[I_{s c}+K_{t}\left(T-T_{r e f}\right)\right] \frac{\beta}{1000 W / m^{2}}
$$

where $I_{p h}$, is the photovoltaic current generated by solar irradiation (A), $I_{s c}$ is the PV short circuit current at $25^{\circ} \mathrm{C} / \mathrm{kW} / \mathrm{m}^{2}, K_{t}$ is temperature coefficient of cell's short circuit current, $T_{r e f}$ is the PV reference temperature $\left(298^{\circ} \mathrm{K}\right)$, and $\beta$ is the irradiation intensity $\left(\mathrm{W} / \mathrm{m}^{2}\right)$.

$$
I=I_{p h}-I_{o}\left[e^{q V_{d} / n K T}-1\right]
$$

where $I$ is the output current of the PV cell, $I_{o}$ is the saturation current of $\mathrm{PV}$ cell, $q$ is the electron charge $\left(1.6 \times 10^{-19} \mathrm{C}\right), V_{d}$ is the voltage imposed across the

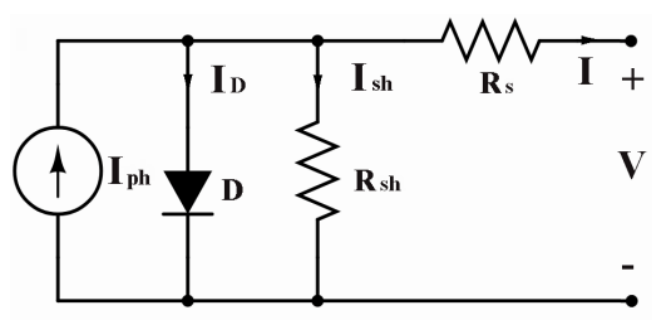

Figure. 2 PV equivalent circuit 
Table 1. Specifications of the PV modules used

\begin{tabular}{|l|l|}
\hline Characteristics & \multicolumn{1}{|c|}{ Value } \\
\hline Maximum power $P_{m p p}$ & $100 \mathrm{~W}$ \\
\hline Maximum Power Voltage $V_{m p p}$ & $18 \mathrm{~V}$ \\
\hline Maximum Power Current $I_{m p p}$ & $5.56 \mathrm{~A}$ \\
\hline Short-Circuit Current $I_{S C}$ & $6.00 \mathrm{~A}$ \\
\hline Open-Circuit Voltage $V_{O C}$ & $22.5 \mathrm{~V}$ \\
\hline Temperature coefficient of $V_{O C}$ & $-0.33 \% /{ }^{0} \mathrm{C}$ \\
\hline Temperature coefficient of $I_{S C}$ & $-0.0055 \% /{ }^{0} \mathrm{C}$ \\
\hline
\end{tabular}

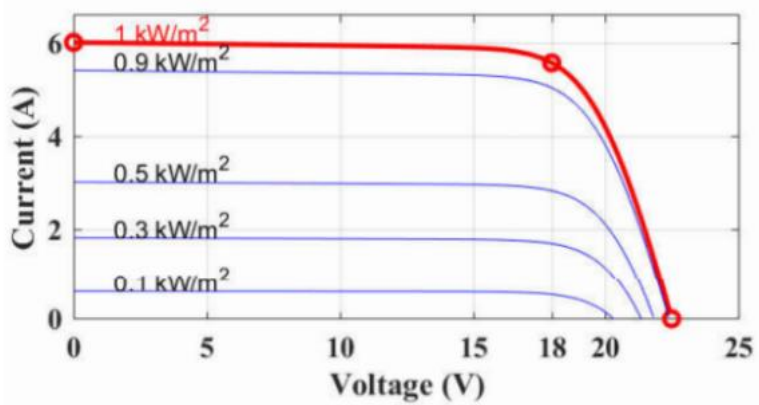

(a)

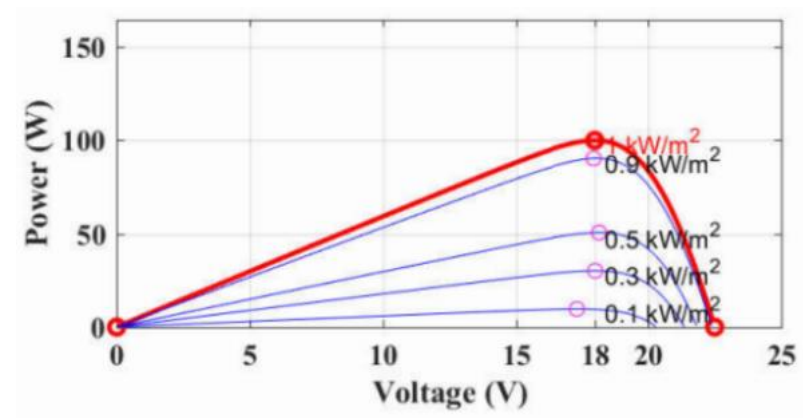

(b)

Figure. 3 PV characteristic curve, a) I-V and b) P-V

cell, $n$ is the ideal factor (1.7), $K$ is Boltzmann's constant $\left(1.38 \times 10^{-23} \mathrm{~J} / \mathrm{K}\right), T$ is the cell temperature (K).

This study used monocrystalline PV panels with a capacity of $100 \mathrm{WP}$. The specifications of the PV panels are presented in Table 1. The current-voltage $(\mathrm{I}-\mathrm{V})$ and power-voltage $(\mathrm{P}-\mathrm{V})$ characteristic curves are shown in Fig. 3. In this study, the PV model at the system simulation steps uses the model provided by MATLAB/SIMULINK. The parameters of the PV model are filled in according to the PV panel specification data from the manufacturer. In the experimental steps, the PV model uses a PV emulator whose irradiation value can be programmed. The PV power capacity in the simulation model and PV emulator is the same as $100 \mathrm{Wp}$.

\subsection{Characteristics of BLDC motor-driven water pump}

Pressurized irrigation networks require a water supply at a certain pressure. Generally, this supply is obtained from the water reservoir tank and pumped into the irrigation network. This system uses a BLDC motor-driven centrifugal pump. The BLDC motor has an equivalent circuit similar to a 3-phase synchronous motor, as shown in Fig. 1. The BLDC motor drive uses a three-phase voltage source inverter (VSI) with an electronic commutation or phase controller based on the rotor position via a Hall sensor. The method used in this electronic commutation is a six-step method. The stator current is directly proportional to the DC link voltage $\left(V_{d c}\right)$ at the VSI [25]. The angular speed of the motor is directly proportional to the stator current, according to Eq. (3).

$$
\omega_{m}=\frac{e_{a} i_{a}+e_{b} i_{b}+e_{c} i_{c}}{T_{m}}
$$

The water pump and the BLDC motor are connected in one shaft, so the pump speed is the same as the BLDC motor speed. The characteristics of the BLDC motor used in this system are listed in Table 2. The centrifugal pump used in this study has a headflow rate characteristic curve, as shown in Fig. 4. The maximum head $\left(H_{p}\right)$ of the pump was $27 \mathrm{~m}$, and the maximum flow rate $\left(Q_{p}\right)$ was $80 \mathrm{l} / \mathrm{m}$. The maximum pump efficiency was achieved when the flow rate was $50 \mathrm{l} / \mathrm{m}$. The hydraulic power of the pump output is called the water horsepower $\left(P_{w h p}\right)$ calculated based on Eq. (4).

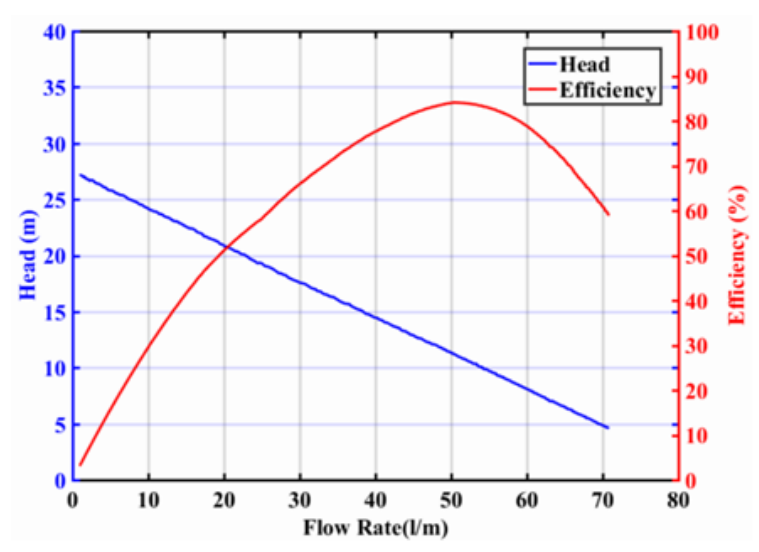

Figure. 4 Head-Capacity curve characteristic of centrifugal pump.

Table 2. BLDC motor parameters.

\begin{tabular}{|l|l|}
\hline \multicolumn{1}{|c|}{ Parameters } & \multicolumn{1}{c|}{ Value } \\
\hline Rated power & $125 \mathrm{~W}$ \\
\hline Rated speed & $3000 \mathrm{RPM}$ \\
\hline Rated voltage & $24 \mathrm{~V}$ \\
\hline Poles & 4 \\
\hline Back EMF Constant & $12 \mathrm{~V} / \mathrm{kRPM}$ \\
\hline Phase resistance & $0.3 \Omega$ \\
\hline Phase inductance & $0.00035 \mathrm{mH}$ \\
\hline
\end{tabular}

DOI: $10.22266 /$ ijies2022.0430.39 


$$
P_{w h p}=\rho g H_{p} Q_{p}
$$

where, $\rho$ is the density of water $(1000 \mathrm{~kg} / \mathrm{m} 3)$, and $\mathrm{g}$ is the gravitational constant, $9.8 \mathrm{~m} / \mathrm{s} 2$.

The correlation between the electric power of the pump ( $\left.P_{i_{-} \text {pump }}\right)$ and $P_{w h p}$ is given by Eq. (5).

$$
P_{i_{-} p u m p}=\frac{P_{w h p}}{\eta_{m} \eta_{p}}
$$

where $\eta_{m}$ is the efficiency of the BLDC motor, and $\eta_{p}$ is the efficiency of the water pump head. The value of $\eta_{m}$ is approximately 0.85 , and $\eta_{p}$ is approximately 0.80 .

\subsection{Design of the boost converter}

The boost converter is an actuator of the MPPT, which functions to increase the voltage from the PV output to the load. This boost converter has the configuration shown in Fig. 1, consisting of inductor $\mathrm{L} 1$, fast recovery diode $\mathrm{D} 1$, capacitor $\mathrm{C} 2$, and MOSFET switch S0. The MPPT controller controls the boost converter via S0 using a pulse width modulation (PWM) signal. The signal is representative of the calculation results of the HKF control method.

The converter output voltage $V_{\text {out }}$ is calculated based on Eq. (6), and the converter output power $P_{\text {out }}$ is obtained by Eq. (7). The relationship between the converter input power $P_{\text {in }}$ and duty cycle $(D)$ according to Eq. (8).

$$
V_{\text {out }}=\frac{V_{\text {in }}}{1-D}
$$

\begin{tabular}{|c|c|c|c|}
\hline \begin{tabular}{|c|} 
Parame \\
ters
\end{tabular} & Expression & Data & $\begin{array}{c}\text { Valu } \\
\text { e }\end{array}$ \\
\hline$D$ & $D=\frac{V_{\text {out }}-V_{\text {in }}}{V_{\text {out }}}$ & $\begin{array}{l}V_{\text {in }}=18 \mathrm{~V} \\
V_{\text {out }}=24 \mathrm{~V}\end{array}$ & 0.25 \\
\hline$L_{1}$ & $L_{1}=\frac{D V_{\text {in }}}{f_{\text {sw }} \Delta I_{\text {out }}}$ & $\begin{array}{l}f_{\text {sw }}=20 \mathrm{kHz} \\
I_{L}=3.3 \mathrm{~A} \\
\begin{aligned} \Delta I_{\text {out }} & =0.05 I_{\text {out }} \\
& =0.165 \mathrm{~A}\end{aligned}\end{array}$ & $\begin{array}{c}1.4 \\
\mathrm{mH}\end{array}$ \\
\hline$C_{2}$ & $\begin{array}{c}\omega=\frac{2 \pi N_{r} P}{120} \\
I_{\text {out }}=\frac{P_{\text {mpp }}}{V_{\text {out }}} \\
C=\frac{I_{\text {out }}}{6 \omega \Delta V_{\text {out }}}\end{array}$ & $\begin{aligned} P & =4 \\
N_{r} & =3000 \mathrm{rpm} \\
V_{\text {out }} & =24 \mathrm{~V} \\
P_{\text {mpp }} & =100 \mathrm{~W} \\
\Delta V_{\text {out }} & =0.02 V_{d c} \\
& =0.6 \mathrm{~V}\end{aligned}$ & $\begin{array}{l}1.8 \\
\mathrm{mF}\end{array}$ \\
\hline
\end{tabular}

Table 3. DC boost converter design parameters

$$
\begin{gathered}
P_{\text {out }}=\frac{V_{\text {out }}^{2}}{R_{L}}=\frac{V_{\text {in }}^{2}}{(1-D)^{2} R_{L}} \\
P_{\text {in }}=\frac{1}{\eta_{\text {conv }}} P_{\text {out }}=\frac{1}{\eta_{\text {conv }}} \frac{V_{\text {in }}^{2}}{(1-D)^{2} R_{L}}
\end{gathered}
$$

The parameters of the boost converter are calculated based on the equation in Table 3 . The boost converter efficiency value $\left(\eta_{\text {conv }}\right)$ depends on the quality of the converter components and generally ranges from $80 \%$ to $98 \%$.

\subsection{Topology of pressurized irrigation network}

The proposed pressurized irrigation network comprises several outlets that supply water to a particular irrigation sector. Each outlet or lateral has several emitters from which water exits to the land. Emitter water discharge is influenced by emitter type and IOP. The relationship between the dripper discharge and IOP of the emitters according to Eq. (9) [26].

$$
q_{j}=K_{d} H^{x}
$$

Where $q_{j}$ the discharge of dripper $1 / \mathrm{h}$ is, $K_{d}$ is the coefficient of the dripper, $\mathrm{H}$ is the IOP (m), and $\mathrm{x}$ is the exponent for the flow regime. Based on Eq. (7) shows that the relationship between IOP and emitter discharge is not linear. Therefore, in pressurized irrigation systems, it is recommended that IOP be maintained at a certain pressure. The IOP set point for this system was 8 psi or $5.63 \mathrm{~m}$.

The water discharge requirement for each sector is calculated based on Eq. (10).

$$
Q_{j}=n_{j} q_{j}
$$

Where $Q_{j}$ the flow of a specific sector (j) is, $n_{j}$ is the number of emitters per sector, and $q_{j}$ is the emitter discharge $(\mathrm{l} / \mathrm{h})$. The value of $q_{j}$ in this system is $4 \mathrm{l} / \mathrm{h}$ with $n_{j}=300$, so the value of $Q_{j}$ is $1200 \mathrm{l} / \mathrm{h}$. This irrigation network was assumed to be flat, and the emitter type was drip-line. The hydraulic capacity of each sector $\left(P_{j}\right)$ in watts was calculated based on Eq. (11).

$$
P_{j}=\rho g H_{r j} Q_{j}
$$

\section{The optimization and control design}

The functional diagram of the HKF method is shown in Fig. 5. The estimated MPP voltage generated by the Kalman filter is compared with the actual PV voltage resulting in a voltage difference 
called voltage error. The voltage error $(V E)$ and the change in voltage error $(\Delta V E)$ then become input for the FLC to control the boost converter so that the PV output power reaches MPP.

\subsection{Kalman filter design for MPPT}

The Vmpp estimation process carried out by the Kalman filter proceeds in two stages. The first step is the prediction state, and the second step is the measurement update. The two steps are iterated to reduce noise, and the covariance error is zero [17]. The prediction state, also known as the time update, is made up of two steps: voltage prediction and prior error covariance. The voltage prediction is obtained by Eq. (12), and the prior error covariance is calculated based on Eq. (13).

$$
\begin{gathered}
\widehat{V}_{k}^{-}=\widehat{V}_{k-1}+M \frac{\Delta P_{p v, k-1}}{\Delta V_{p v, k-1}} \\
P_{k}^{-}=P_{k-1}+Q
\end{gathered}
$$

where $\widehat{V}_{k}^{-}$is the predicted Vmpp at $\mathrm{k}^{\text {th }}$ iterations, $\widehat{V}_{k-1}$ is the updated estimate of the Vmpp in $(\mathrm{k}-1)^{\text {th }}$ iterations, $\Delta P_{p v, k-1} / \Delta V_{p v, k-1}$ is the instantaneous

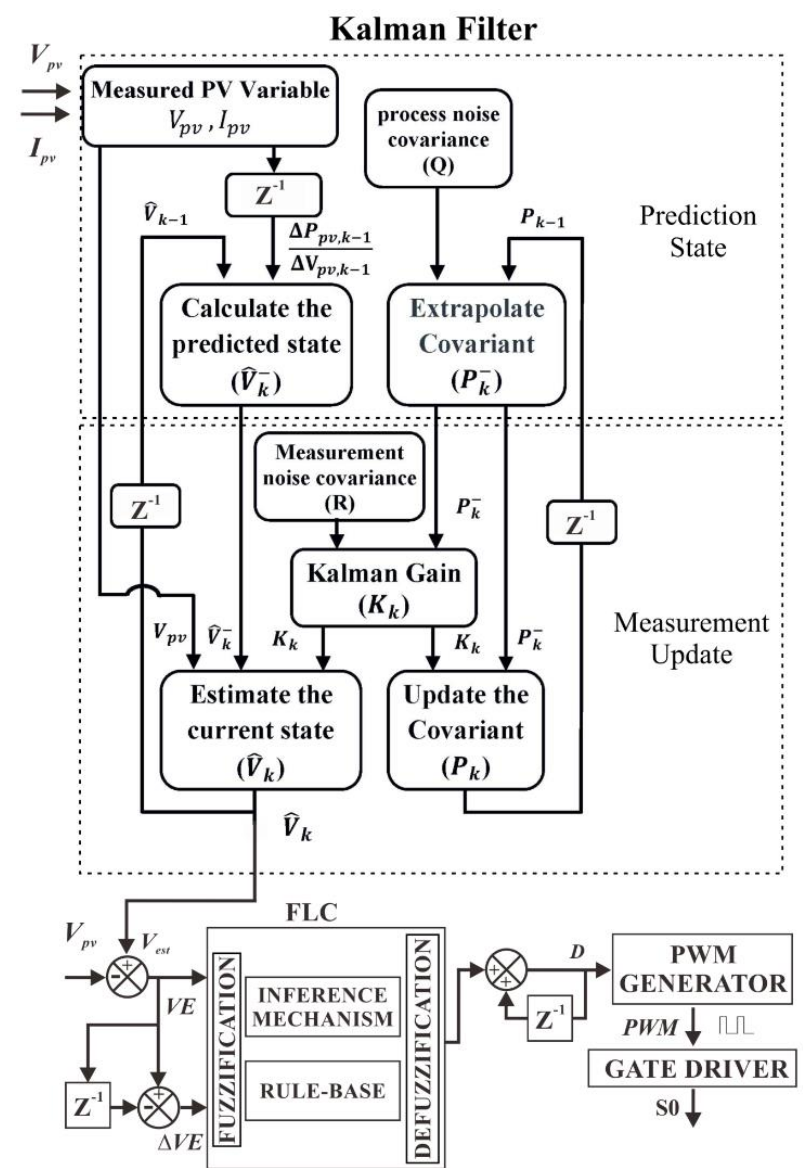

Figure. 5 Functional diagram of the HKF algorithm power slope at $(\mathrm{k}-1)^{\text {th }}$ iterations. $M$ is the scaling factor. The scaling factor in this system is 0.5 , which is obtained through trial and error. $P_{k}^{-}$is the a priori error covariance in $\mathrm{k}^{\text {th }}$ iterations, $P_{k-1}$ is the posteriori error covariance in $(\mathrm{k}-1)^{\mathrm{th}}$ iterations, and $Q$ is the process noise covariance. The value of $Q$ in this system is 0.01 .

The instantaneous power slope at $(\mathrm{k}-1)^{\text {th }}$ iteration $\mathrm{k}-1$ is calculated according to Eq. (14). The P-V curve in Fig. 3 shows that the power slope is positive when the PV voltage is less than Vmpp. The power slope is zero when the PV voltage is Vmpp. The power slope is negative when the PV voltage is greater than Vmpp.

$$
\frac{\Delta P_{p v, k-1}}{\Delta V_{p v, k-1}}=\frac{P_{p v, k-1}-P_{p v, k-2}}{V_{p v, k-1}-V_{p v, k-2}}
$$

The step after the prediction state is a measurement update or is called the correction state. The measurement update corrects the predicted value during the prediction state step. The measurement update has three equations, namely, calculating the Kalman gain $\left(K_{k}\right)$, updating the estimated voltage $\left(\widehat{V}_{k}\right)$ and updating the error covariance $\left(P_{k}\right)$. The Kalman gain was calculated according to Eq. (15).

$$
K_{k}=P_{k}^{-}\left(P_{k}^{-}+R\right)^{-1}
$$

The measurement noise covariance $(R)$ represents the noise distribution at the measurement input given by the sensor. In this system, the value of $R$ is 0.01 . The updated estimate of the PV voltage at the MPP is formulated with Eq. (16), where $V_{p v, k}$ is the PV voltage at $\mathrm{k}^{\text {th }}$ iterations.

$$
\widehat{V}_{k}=\widehat{V}_{k}^{-}+K_{k} \times\left(V_{p v, k}-\widehat{V}_{k}^{-}\right)
$$

The update error covariance $P_{k}$ is obtained based on Eq. (17).

$$
P_{k}=\left(1-K_{k}\right) \times P_{k}^{-}
$$

In the next iteration, $\widehat{V}_{k}$ becomes $\widehat{V}_{k-1}$ and $P_{k}$ becomes $P_{k-1} \cdot \widehat{V}_{k}$ is used as a setpoint for the MPP tracking control.

\subsection{Design of fuzzy logic controller}

The fuzzy logic controller (FLC) controls the DC boost converter so that the PV output power reaches the MPP. The FLC inputs are the PV voltage error $(V E)$ and the $\mathrm{PV}$ voltage error change $(\Delta V E)$. The PV voltage error is the difference between the estimated PV voltage from the Kalman filter and the actual PV 
voltage. The FLC output is the control signal for the DC boost converter. The position of the FLC in the MPPT system architecture is shown in Fig. 5. Fuzzy control uses linguistic variables instead of mathematical models of dynamic systems [25].

The FLC in this system uses the Mamdani method, which is often known as the max-min method. There are three stages for output control: fuzzification, inference mechanism, and defuzzification [27, 28]. Fuzzification converts crisp input values into fuzzy sets. The inference mechanism makes decisionmaking from the fuzzy input set based on the designed logic rules. The results of the inference mechanism were converted into sharp outputs through the defuzzification process.

The voltage error $(V E)$ and delta voltage error $(\triangle V E)$ as FLC input variables are transformed into input membership functions, as shown in Fig. 6(a) and $6(\mathrm{~b})$. The input membership function of $V E$ is divided into five linguistic labels, including high negative error (HNE), low negative error (LNE), zero error (ZE), high positive error (HPE), and low positive error (LPE). The input membership function

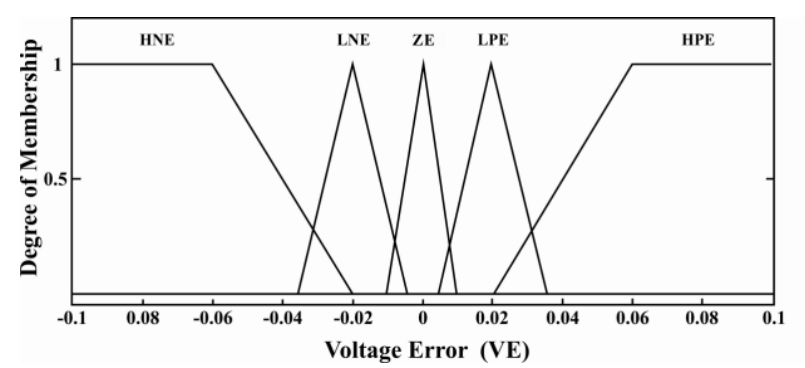

(a)

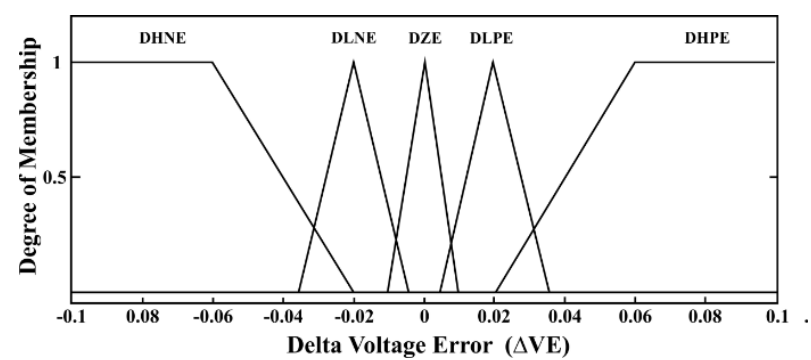

(b)

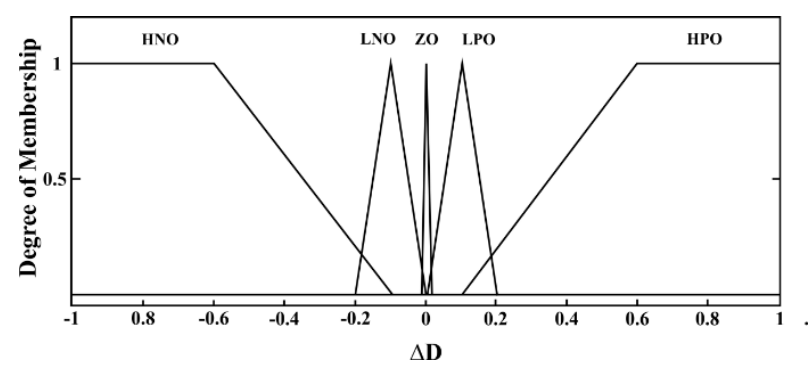

(c)

Figure. 6 Fuzzy membership function of: (a) voltage error, (b) delta voltage error, and (c) output FLC of $\triangle \mathrm{VE}$ is divided into five linguistic labels: delta high negative error (DHNE), delta low negative error (DLNE), delta zero error (DZE), delta low positive error (DLPE), and delta high positive error (DHPE).

The FLC output is a control signal represented as a step size $\mathrm{D}$. The magnitude of $\mathrm{D}$ results from the sum of the previous D values with the FLC output. The FLC output membership function is shown in Fig. 6(c). The FLC output function is divided into five linguistic labels, which include the high negative output (HNO), low negative output (LNO), zero output (ZO), low positive output (LPO), and high positive output (HPO). The logical rules built into the inference mechanism are based on human experience embodied through language variables and rule-based. The FLC rule in the proposed method uses 25 rule bases represented in a symmetrical form, as shown in Table 4. There are several defuzzification methods in the Mamdani method, and this system uses the centroid method. The crisps output (z) is obtained by taking the center point of the fuzzy area based on Eq. (18).

$$
Z=\frac{\sum_{i=1}^{n} z_{i} \mu\left(z_{i}\right)}{\sum_{i=1}^{n} \mu\left(z_{i}\right)}
$$

where $z$ is the center point of the fuzzy area, $z_{i}$ is the sample element, $\mu\left(z_{i}\right)$ is the membership function, and $\mathrm{n}$ represents the number of elements in the sample.

\section{Simulation and experimental}

\subsection{Simulation setup}

The SPVPIS model was simulated using MATLAB/Simulink. This system consists of a PV model, DC boost converter model, MPPT controller model, BLDC motor model, centrifugal water pump model, irrigation network model, and irrigation sector controller. The HKF method as an MPPT control strategy has input from the PV output voltage and current sensor. The values of the $Q$ and $R$ parameters of the Kalman filter are 0.01 and 0.01 , respectively. The HKF output is a control signal in the form of PWM to control the boost converter so that

Table 4. Fuzzy rule-based

\begin{tabular}{|c|c|c|c|c|c|}
\hline $\boldsymbol{V V E} \backslash$ & HNE & LNE & ZE & LPE & HPE \\
\hline DHNE & HNO & HNO & LNO & HPO & HPO \\
\hline DLNE & HNO & LNO & LNO & LPO & HPO \\
\hline DZE & LNO & LNO & ZO & LPO & LPO \\
\hline DLPE & HNO & LNO & LPO & LPO & HPO \\
\hline DHPE & HNO & HNO & LPO & HPO & HPO \\
\hline
\end{tabular}


the PV output power is always at the MPP.

The pressurized irrigation system (PIS) model resulted from the integration of several models, namely BLDC motors, centrifugal water pumps, irrigation networks, and irrigation sector controllers. The irrigation network was divided into ten sectors with a capacity of $10 \mathrm{~W}$ in each sector. The number of active sectors increased if the PV output power increased by more than $10 \mathrm{~W}$, and vice versa. The irrigation sector is regulated by a multi-sector controller based on the PV output power through activation of the solenoid valve. The match between the PV output power and irrigation capacity will result in an IOP closer to the setpoint and more stable.

SPVPIS model testing has been carried out to determine the characteristics and performance of the proposed method. The observed MPPT variables include power, voltage, and current at the PV output. The observed PIS variables include motor speed $(\mathrm{N})$ in the RPM, motor torque (T) in Nm, stator back EMF in volts and, IOP in psi. Perturb and Observe $(\mathrm{P} \& \mathrm{O})$ is another method used for comparison. The $\mathrm{P} \& \mathrm{O}$ method was applied to the same SPVPIS to determine the advantages of the HKF method over other methods.

The test was performed by changing the PV irradiation to several patterns. This study has three test patterns: a unit step pattern and two natural data patterns. The unit step pattern was used to determine the response speed and steady-state of the MPPT system. Natural data patterns were used to assess the ability of the MPPT system to adapt to natural changes during irradiation. The data pattern was obtained from daily solar radiation recordings on the Institut Teknologi Sepuluh Nopember (ITS), Surabaya, Indonesia. The ITS PV station has a $16 \mathrm{~kW}$ rooftop photovoltaic power plant installed at coordinates $7^{\circ} 16^{\prime} 52.4892^{\prime \prime} \mathrm{S}, 112^{\circ} 47^{\prime} 50.838^{\prime \prime} \mathrm{E}$. The irradiation pattern used in this test was recorded on June 13, 2021, and July 17, 2021.

The unit step test pattern was shown in Fig. 7. The irradiation pattern started from $300 \mathrm{~W} / \mathrm{m}^{2}$ irradiation for $200 \mathrm{~ms}$, then changed to $400 \mathrm{~W} / \mathrm{m}^{2}$ for $200 \mathrm{~ms}$ and $500 \mathrm{~W} / \mathrm{m}^{2}$ for $200 \mathrm{~ms}$. This test with tiered irradiation

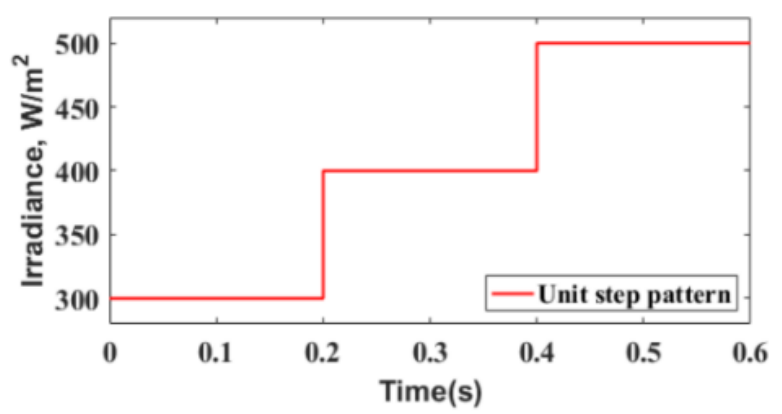

Figure. 7 Unit step pattern for performance test

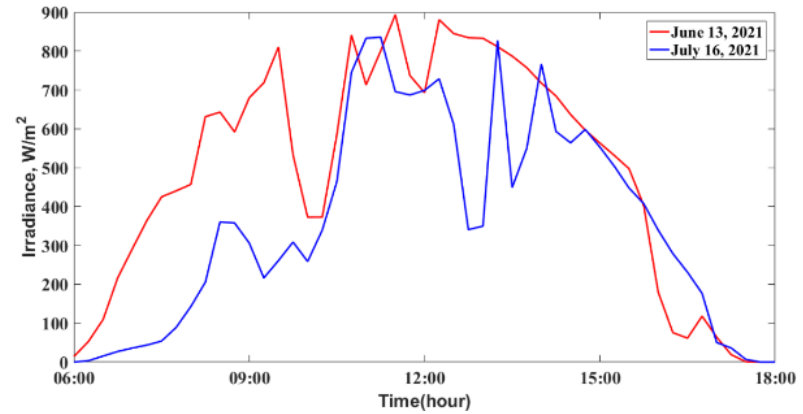

Figure. 8 Daily irradiation at the ITS PV panel station on June 13, 2021, and July 17, 2021

changes is to determine the MPPT response at each different irradiation level. The simulation model was tested with two natural data patterns. The natural data pattern corresponds to the daily solar radiation recorded by the ITS PV panel station. Fig. 8 is 2 data on daily solar irradiance recorded on June 13, 2021, and July 17, 2021. The irradiation value in these data is very volatile because the weather changes rapidly. A sharp decrease in irradiation due to cloud shadows covering the PV panels. This pattern is good enough to test the ability of the MPPT method because the irradiation changes are dynamic. The pattern used to test the simulation has the same irradiation magnitude as the daily irradiation pattern but with a downscaling duration.

\subsection{Simulation performance}

The test results of the SPVPIS simulation using the unit step pattern are shown in Fig. 9. The MPPT response is shown in Fig. 9(a), while the IOP response of the irrigation network is shown in Fig. 9(b). It can be seen that the HKF method can track the MPP quickly and has small steady-state oscillations. Although the $\mathrm{P} \& \mathrm{O}$ method was also successful in tracking MPP, it had larger oscillations than the HKF method. The magnification of the graphic display of the MPPT transition response when the irradiation changes are shown in Fig. 10. The response of the system from the beginning to reach MPP of $30.19 \mathrm{~W}$ at an irradiation of $300 \mathrm{~W} / \mathrm{m}^{2}$ is shown in Fig. 10(a). Fig. 10(b) is the transition response of the system due to irradiation from $300 \mathrm{~W} / \mathrm{m}^{2}$ to $400 \mathrm{~W} / \mathrm{m}^{2}$. Fig. 10 (c) is the transition response from irradiation of $400 \mathrm{~W} / \mathrm{m}^{2}$ to $500 \mathrm{~W} / \mathrm{m}^{2}$. The MPP value of PV panels at $400 \mathrm{~W} / \mathrm{m}^{2}$ irradiation is $40.47 \mathrm{~W}$, and at $500 \mathrm{~W} / \mathrm{m}^{2}$ irradiation is $50.67 \mathrm{~W}$. The rise time and steady-state oscillation values for each transition are summarized in Table 5. The HKF method has an average rise time of $1.9 \mathrm{~ms}$ and an average steady-state oscillation amplitude of $0.65 \mathrm{~W}$ with a frequency of $683.54 \mathrm{~Hz}$. The P\&O method has an average rise time of $24.5 \mathrm{~ms}$ and an average 


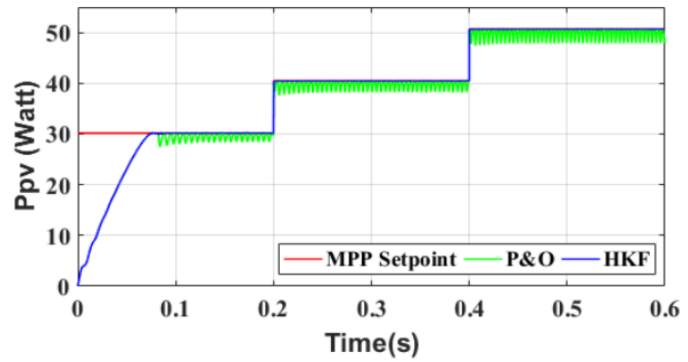

(a)

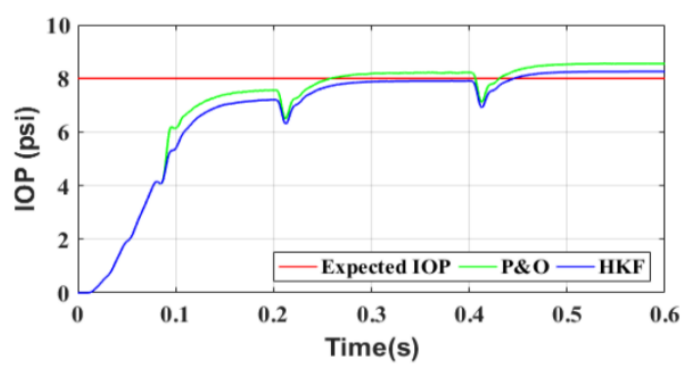

(b)

Figure. 9 SPVPIS simulation test results with unit step pattern, (a) the MPPT response and (b) the IOP response

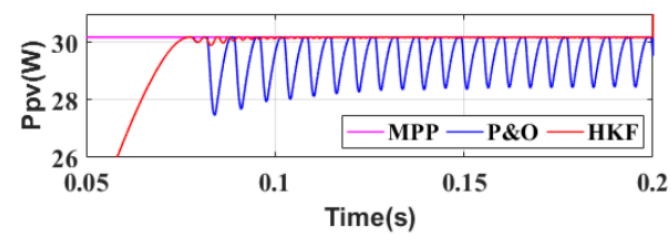

(a)

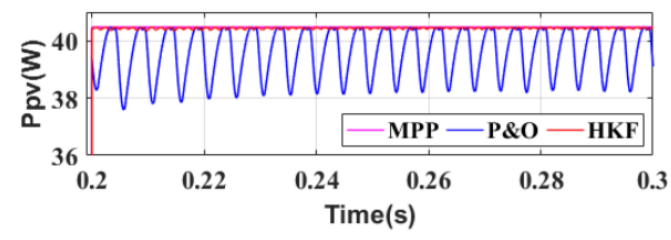

(b)

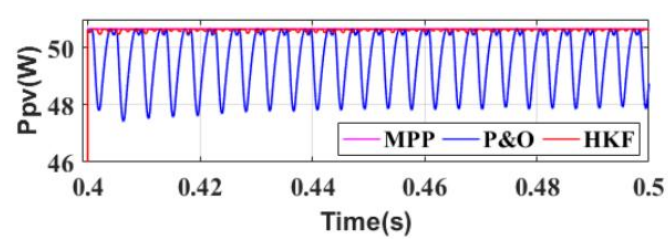

(c)

Figure. 10 Magnification of the MPPT transition response, (a) $0 \mathrm{~W} / \mathrm{m}^{2}$ to $300 \mathrm{~W} / \mathrm{m}^{2}$, (b) $300 \mathrm{~W} / \mathrm{m}^{2}$ to $400 \mathrm{~W} / \mathrm{m}^{2}$, (c) $400 \mathrm{~W} / \mathrm{m}^{2}$ to $500 \mathrm{~W} / \mathrm{m}^{2}$

Table 5. Comparison of the HKF and P\&O method test results

\begin{tabular}{|c|c|c|c|c|}
\hline \multirow{2}{*}{$\begin{array}{c}\text { Irradiance } \\
\left(\mathrm{W} / \mathrm{m}^{2}\right)\end{array}$} & \multicolumn{2}{|c|}{ Rise time (ms) } & \multicolumn{2}{c|}{ Oscillations (W) } \\
\cline { 2 - 5 } & HKF & P\&O & HKF & P\&O \\
\hline 300 & 93 & 110 & 0.03 & 1.75 \\
\hline 400 & 1.7 & 21 & 0.06 & 2.12 \\
\hline 500 & 2.1 & 28 & 0.07 & 2.75 \\
\hline
\end{tabular}
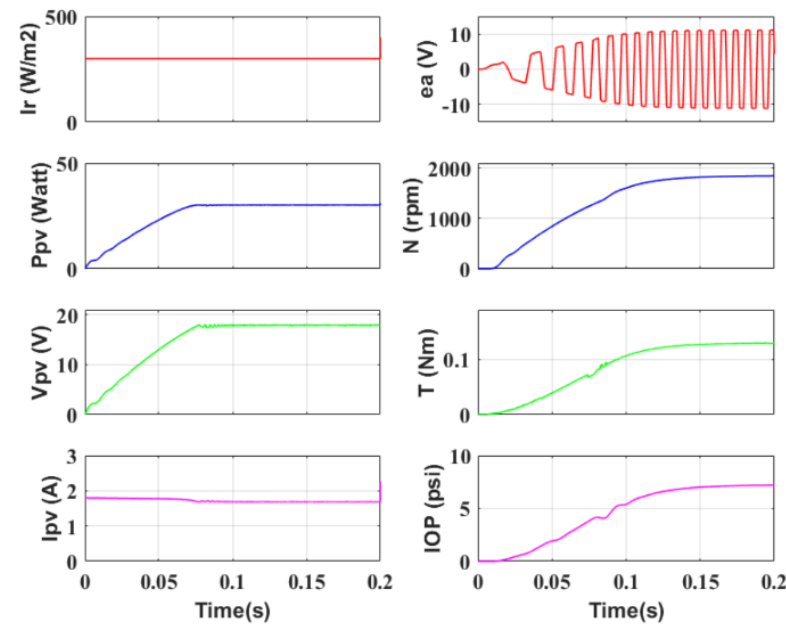

Figure. 11 Responses of PIS at the beginning simulation

steady-state oscillation amplitude of $2.4 \mathrm{~W}$ with a frequency of $211.27 \mathrm{~Hz}$. At the beginning of the simulation, the rise time was much longer than that after passing the first steady-state. This is caused by the BLDC motor starting and initial charging of the capacitor in the boost converter. Starting on a BLDC motor requires an inrush current of 3-5 times the nominal current.

Compared to the $\mathrm{P} \& \mathrm{O}$ method, the HKF method has a shorter rise time and steady-state oscillation. The fast response and low steady-state oscillation in the HKF method are due to the ability of the Kalman filter to estimate the MPP and the ability of the FLC to regulate the duty cycle step size of the boost converter. The accuracy of this FLC control is strongly influenced by the accuracy of the membership function design based on the control logic and the characteristics of the boost converter. The conventional P\&O method has a fixed duty cycle step size, whereas the HKF method has a variable duty cycle step size. The duty cycle step size is based on the difference between the actual PV output voltage and estimated Vmpp. Therefore, if the Vmpp estimation by the Kalman filter is inaccurate, FLC control will be inaccurate.

The characteristics of the IOP response to changes in irradiation are shown in Fig. 8(b). It can be seen that the IOP on the PIS can reach the expected value even though the PV output power changes. At the beginning of the simulation, the IOP rise time was longer than that after passing the first steady-state because of the pump starting process. The process variables for the MPPT and PIS at the beginning of the simulation are shown in Fig. 11. It can be seen that the PV output current when the BLDC motor starts is $1.8 \mathrm{~A}$. This value is the maximum output current of the $100 \mathrm{Wp}$ PV panel when the irradiation is $300 \mathrm{~W} / \mathrm{m}^{2}$. The speed and torque of the BLDC 
motor start to be constant when the MPPT reaches its optimum power, resulting in a constant IOP. The residual pressure due to the reduced number of active sectors resulted in a temporary spike in IOP. The momentary decline in IOP results from an increase in the number of active sectors.

The simulation test results using natural irradiation pattern data recorded on June 13, 2021, are shown in Fig. 12(a) and 12(b). The test results with natural irradiation pattern data recorded on July 16 , 2021, are shown in Fig. 13(a) and 13(b).
The system response to the two test patterns shows that the HKF and P\&O methods can track MPP values at all irradiation levels even though the irradiation changes dynamically. However, the HKF method is superior to the conventional $\mathrm{P} \& \mathrm{O}$ method because it has a smaller steady-state oscillation amplitude. The largest oscillation amplitudes of the HKF method tested with irradiation patterns on June13, 2021, and July 17, 2021, were $0.33 \mathrm{~W}$ and $0.36 \mathrm{~W}$, respectively, while the $\mathrm{P} \& \mathrm{O}$ method was 5.06 $\mathrm{W}$ and $5.15 \mathrm{~W}$, respectively. The PIS response shows

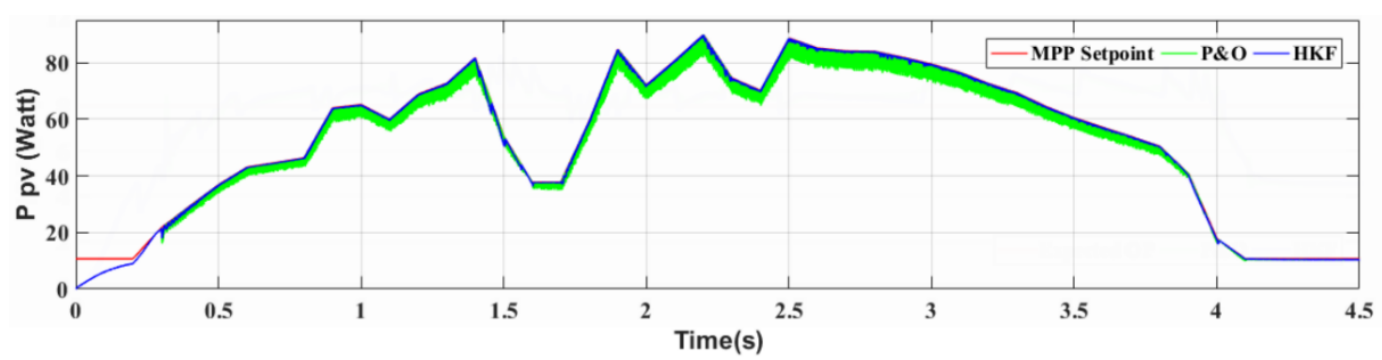

(a)

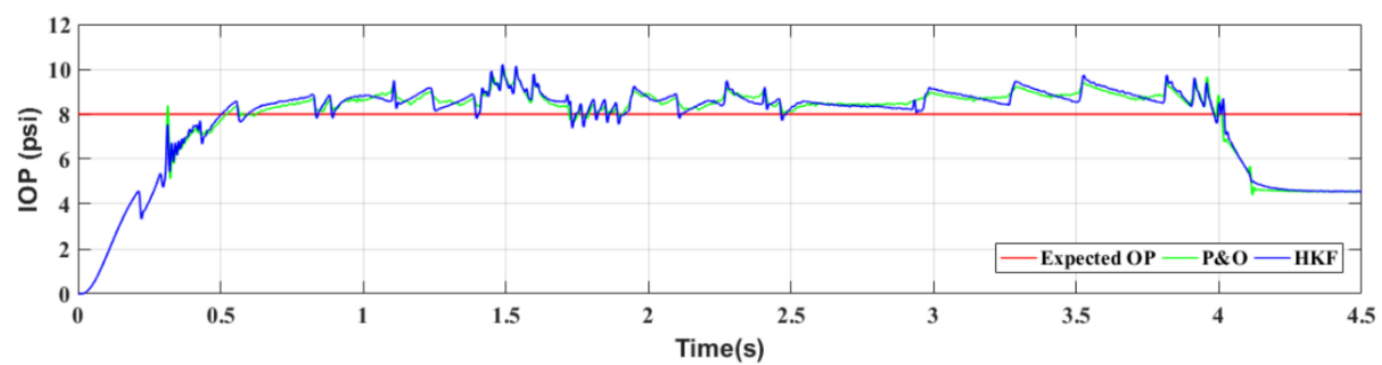

(b)

Figure. 12 Simulation test results using natural irradiation patterns recorded by ITS PV station on June 13, 2021, (a) MPPT control response and (b) irrigation network response

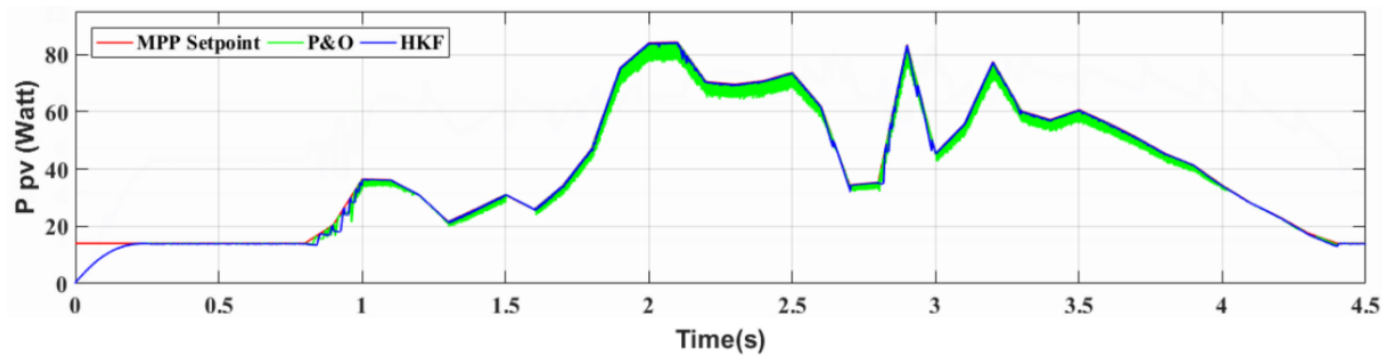

(a)

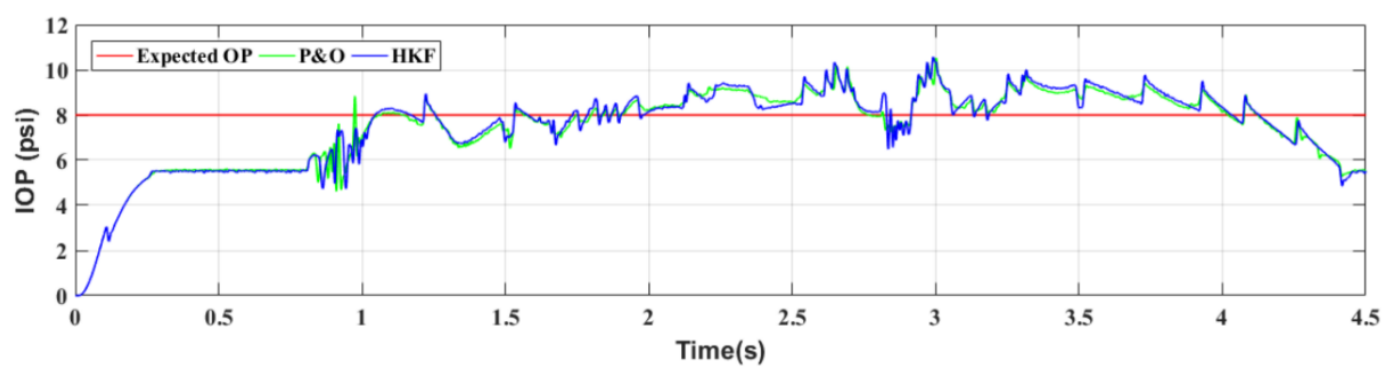

(b)

Figure. 13 Simulation test results using natural irradiation patterns recorded by ITS PV station on July 17, 2021:

(a) MPPT control response and (b) irrigation network response 

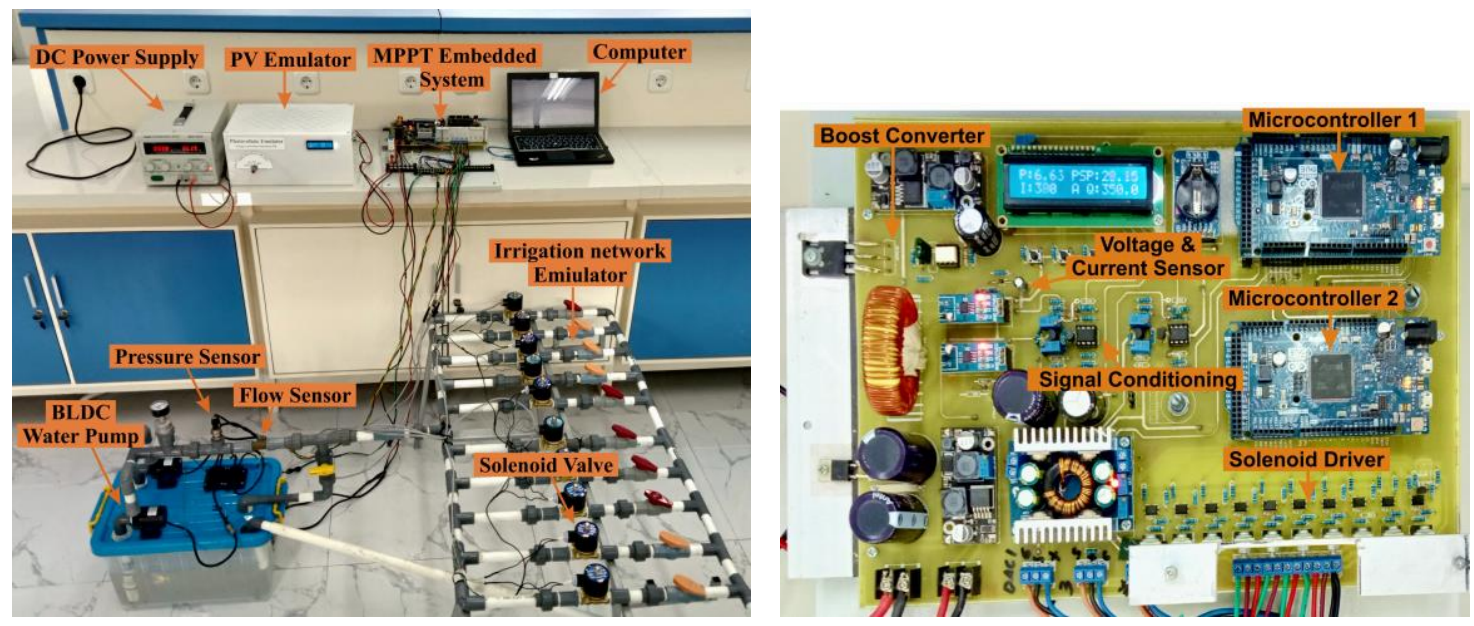

Figure. 14 SPVPIS prototype used to validate the proposed method: (a) Photo of SPVPIS prototype and (b) Embedded system

IOP fluctuating 0-2 psi around the planned value of 8 psi. This fluctuation results from the irrigation sector controller using the on/off method. However, the concept of regulating IOP by controlling irrigation capacity according to the PV output power has succeeded in making IOP more stable.

\subsection{Experimental setup}

The performance of the proposed MPPT method was validated using the SPVPIS prototype. The prototype consists of an MPPT module, an irrigation control module, and a pressurized irrigation network. The pressurized irrigation emulator consists of a BLDC pump, water reservoir, pressure sensor, flow sensor, solenoid valve, stop valve, and parallel pipe. The integration between the embedded systems, PV panels, and pressurized irrigation networks into the SPVPIS is shown in Fig. 14(a).

The MPPT hardware and irrigation control modules were built into an embedded system, as shown in Fig. 14(b). The MPPT system consists of an ARM-32 microcontroller, boost converter, Hall effect-based current sensor, voltage sensor, and signal conditioner. The irrigation control system includes an ARM-32 microcontroller, signal conditioner, water pressure sensor, water flow sensor, and solenoid valve driver. The output signal from the voltage, current, and water pressure sensors is amplified by a conditioning signal and then converted to digital data using a 10-bit Analog to Digital converter (ADC) in the microcontroller. Data from the ADC filtered using a moving average filter to reduce the noise. The communication between the two microcontrollers uses an asynchronous serial.

The HKF method algorithm implemented in microcontroller 1 has a program flow chart, as shown

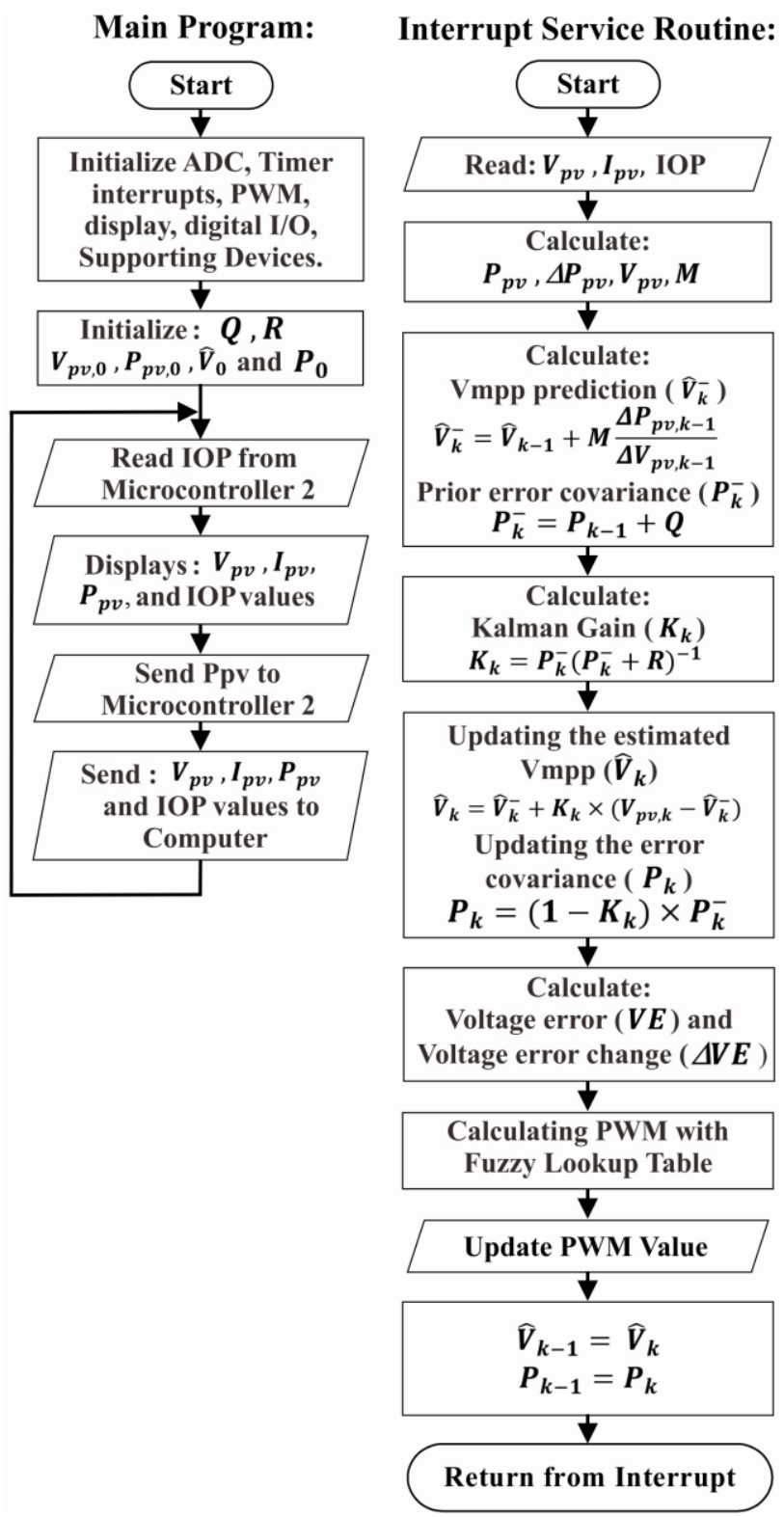

Figure. 15 Flow chart of the HKF method implemented in the microcontroller 
in Fig. 15. The program flow consists of 2 parts: the main program and the interrupt service routine (ISR).

The main program only reads the IOP value from microcontroller 2, sends the actual PV power value, displays the PV output variable and IOP to the local display, sends this SPVPIS variable measurement data to the computer, and waits for the timer interrupt. The program, which includes PV variable reading, Vmpp estimation with Kalman filter, and FLC algorithm with a lookup table (LUT), is carried out at ISR. The data sampling process is carried out in the interrupt timer resulting in a stable sampling period.

The SPVPIS hardware was tested using a PV emulator. The PV emulator is a nonlinear power supply capable of producing a current-voltage characteristic similar to a PV panel [29-31]. Testing the MPPT method using a PV emulator is more accessible and scalable. The prototype test was carried out by changing the PV emulator irradiation value with a unit step pattern from $320 \mathrm{~W} / \mathrm{m}^{2}$ to $527 \mathrm{~W} / \mathrm{m}^{2}$ and from $527 \mathrm{~W} / \mathrm{m}^{2}$ to $683 \mathrm{~W} / \mathrm{m}^{2}$.

\subsection{Experiment Performance}

Measurements of voltage and current at the PV output and IOP carried out by the microcontroller have average errors of $0.6 \%, 2.5 \%$, and $1 \%$, respectively. Testing the prototype for $55 \mathrm{~s}$ with a rapidly changing irradiation pattern results in a response, as shown in Fig. 16. For comparison, the graph also includes the results of testing the simulation model with the same treatment. The HKF-based MPPT response is shown in Fig. 16(a). It can be seen that the application of the HKF method on the prototype can track and condition the PV output power to reach the MPP. The system rise time in tracking the MPP when the irradiance is changed from $320 \mathrm{~W} / \mathrm{m}^{2}$ to $527 \mathrm{~W} / \mathrm{m}^{2}$ or from 527 $\mathrm{W} / \mathrm{m}^{2}$ to $683 \mathrm{~W} / \mathrm{m}^{2}$ is $1.02 \mathrm{~s}$. The rise time value of the prototype test results was greater than that of the simulation results. Some factors that cause a larger prototype rising time are less than ideal component characteristics, low computational speed of the microcontroller, the time lag in the moving average filter, and relatively slow sampling time. The sampling time on this microcontroller was $1 \mu$ s. The prototype response is faster when using a microcontroller with a higher speed.

The response of the irrigation network to the prototype is shown in Fig. 16(b). Although the solar irradiation changed, the IOP variable was relatively stable around the expected value of 8 psi. There is a slight decrease in IOP when the PV power changes by more than $30 \mathrm{~W}$ owing to changes in the number of active irrigation sectors. The IOP ripple in the simulation is higher and more numerous than in the experiment because the water pressure sensor is less sensitive to small and sudden pressure changes and the influence of the moving average filter in the microcontroller algorithm.

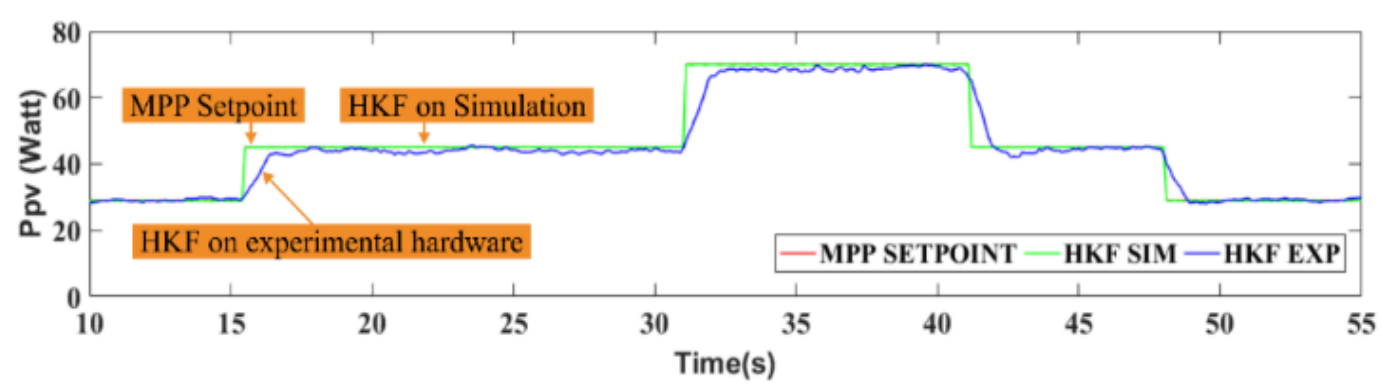

(a)

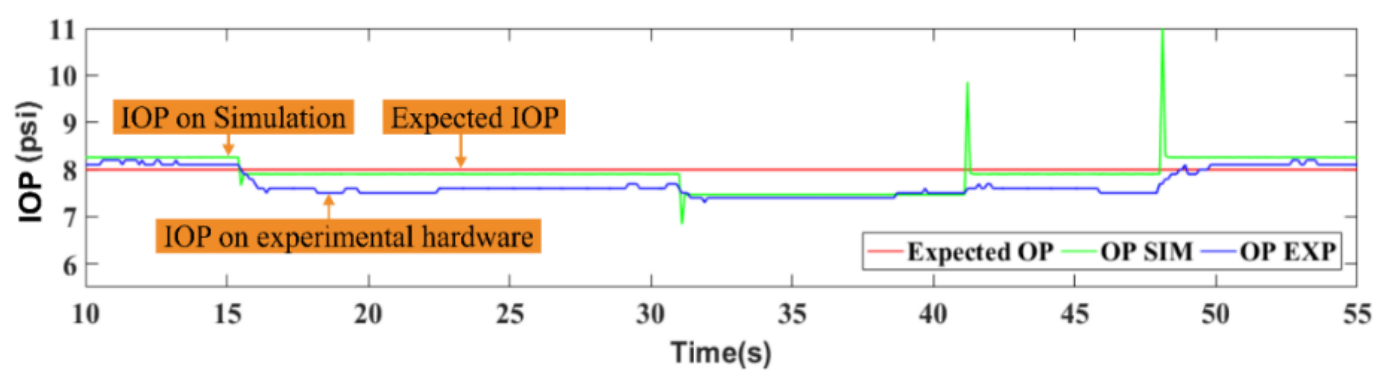

(b)

Figure. 16 Experimental test results with variations in irradiation: (a) MPPT control response and (b) irrigation network response 
Table 6. Comparison of MPPT and irrigation system performance

\begin{tabular}{|c|c|c|c|c|c|c|c|c|}
\hline Performance & $\begin{array}{c}\text { PV } \\
\text { panel }\end{array}$ & $\begin{array}{c}\text { MPPT } \\
\text { Method }\end{array}$ & $\begin{array}{c}\text { DC } \\
\text { Converter }\end{array}$ & $\begin{array}{c}\text { Motor- } \\
\text { pump }\end{array}$ & $\begin{array}{c}\text { Irrigation } \\
\text { type }\end{array}$ & $\begin{array}{c}\text { MPPT } \\
\text { transient } \\
\text { responses }\end{array}$ & $\begin{array}{c}\text { MPPT } \\
\text { steady-state } \\
\text { oscillation }\end{array}$ & $\begin{array}{c}\text { IOP } \\
\text { response }\end{array}$ \\
\hline Ref [11] & Yes & INC & No & BLDC & Surface & Middle & Middle & No \\
\hline Ref [12] & Yes & INC & Cuk & BLDC & Surface & Middle & Middle & No \\
\hline Ref [13] & Yes & INC & Landsman & BLDC & Surface & Middle & Middle & No \\
\hline Ref [14] & Yes & INC & Zeta & BLDC & Surface & Middle & Middle & No \\
\hline Ref [15] & Yes & FLC & Boost & Induction & Surface & Middle & Middle & No \\
\hline Ref [16] & No & No & No & DC Brush & Pressurized & No & No & Stable \\
\hline Ref [17] & Yes & $\begin{array}{c}\text { No } \\
\text { descripti } \\
\text { on }\end{array}$ & $\begin{array}{c}\text { No } \\
\text { description }\end{array}$ & Induction & Pressurized & $\begin{array}{c}\text { No } \\
\text { description }\end{array}$ & $\begin{array}{c}\text { No } \\
\text { description }\end{array}$ & Stable \\
\hline Proposed & Yes & HKF & Boost & BLDC & Pressurized & low & low & Stable \\
\hline
\end{tabular}

\subsection{Performance comparison Of MPPT and irrigation methods}

The comparison of the performance of the proposed system, namely SPVPIS based on the HKFMPPT method, against other irrigation systems in the literature is shown in Table 6. The comparison includes PV as an energy source, the MPPT method used, the type of DC converter, the kind of pump driving motor, the type of irrigation, MPPT transient response, and MPPT steady-state, and IOP response. Other irrigation systems in the literature have not yet integrated the optimization of PV output power with irrigation capacity. Some irrigations that optimize irrigation capacity have not been synchronized with energy sources. This synchronization is needed to reduce the number of PV panels. MPPT with the HKF method has a much better performance than the system in the literature. MPPT HKF method has a faster transient response and smaller power oscillations in MPP.

\section{Conclusions}

The proposed HKF method was applied to the SPVPIS without energy storage. The system was simulated using MATLAB/Simulink and implemented in a laboratory-scale prototype. The simulation test results using the unit step pattern show that the system has an average rise time of $1.9 \mathrm{~ms}$ and an average steady-state oscillation amplitude of 0.65 $\mathrm{W}$ with a frequency of $683.54 \mathrm{~Hz}$. The simulation test results on the SPVPIS model using natural irradiation patterns show that the HKF method can achieve MPP with a maximum steady-state oscillation of $0.36 \mathrm{~W}$. The performance of the HKF method is much better than that of the conventional $\mathrm{P} \& \mathrm{O}$ method because it has a shorter rise time and steady-state oscillation. The prototype test results using the unit step pattern showed that the HKF method achieved MPP at all irradiation levels with a rise time of $1.02 \mathrm{~s}$. The fast response and low steady-state oscillation in the HKF method are due to the ability of the Kalman filter to estimate the Vmpp and the ability of the FLC to regulate the duty cycle step size of the boost converter.

The success of the HKF method in optimizing PV output power results in better irrigation performance and precision. The simulation and prototype test results showed that the IOP in the PIS was maintained around the expected value. However, the PV output power and the number of irrigation sectors have changed.

\section{Conflicts of Interest}

The authors declare no conflict of interest.

\section{Author Contributions}

In this research article author contributions are as follows: "Conceptualization and methodology, Suwito Suwito, and Mochamad Ashari; software, Suwito Suwito; validation, Suwito Suwito, Mochamad Ashari and Muhammad Rivai; formal analysis, Suwito Suwito, Mochamad Ashari and Muhammad Rivai; investigation, Suwito Suwito; resources, Suwito Suwito; data curation, Suwito Suwito; writing — original draft preparation, Suwito Suwito; writing - review and editing, Suwito Suwito, Mochamad Ashari, Muhammad Rivai, and M. Anis Mustaghfirin; visualization, Suwito Suwito; supervision, Mochamad Ashari, Muhammad Rivai, and M. Anis Mustaghfirin".

\section{Acknowledgments}

The author would like to thank the Directorate of Research and Community Service (DRPM) of Institut Teknologi Sepuluh Nopember Surabaya (ITS) and the Ministry of Research and Technology / National Research and Innovation Agency of the Republic of Indonesia, who has provided financial support. 


\section{References}

[1] S. O. Grau, P. G. Altozano, F. J. G. Sales, I. B. Peralta, C. I. Marquez, M. Gasque, and S. S. Chilet, "Photovoltaic water pumping: Comparison between direct and Lithium Battery Solutions", IEEE Access, Vol. 9, pp. 101147101163, 2021.

[2] S. C. Wang, H. Y. Pai, G. J. Chen, and Y. H. Liu, "A fast and efficient maximum power tracking combining simplified state estimation with adaptive perturb and observe", IEEE Access, Vol. 8, pp. 155319-155328, 2020.

[3] A. Hamidat, B. Benyoucef, and T. Hartani, "Small-scale irrigation with photovoltaic water pumping system in Sahara regions", Renewable Energy, Vol. 28, No. 7, pp. 1081-1096, 2003.

[4] H. A. Sher, A. F. Murtaza, A. Noman, K. E. Addoweesh, K. A. Haddad, and M. Chiaberge, "A new sensorless hybrid MPPT algorithm based on fractional short-circuit current measurement and $\mathrm{P} \& \mathrm{O}$ MPPT", IEEE Transactions on Sustainable Energy, Vol. 6, No. 4, pp. 1426-1434, 2015.

[5] A. Hamidet, U. Subramaniam, R. M. Elavarasan, K. Raju, M. Diaz, N. Das, K. Mehmood, A. Karthick, M. Muhibbullah, and O. Boubaker, "Design of efficient off-grid solar photovoltaic water pumping system based on improved fractional open circuit voltage MPPT technique", International Journal of Photoenergy, Vol. 2021, pp. 1-18, 2021.

[6] A. Seyedzadeh, S. Maroufpoor, E. Maroufpoor, J. Shiri, O. B. Haddad, and F. Gavazi, "Artificial intelligence approach to estimate discharge of drip tape irrigation based on temperature and pressure", Agricultural Water Management, Vol. 228, p. 105905, 2020.

[7] V. Zavala, R. L. Luque, J. Reca, J. Martínez, and M. T. Lao, "Optimal management of a multisector standalone direct pumping photovoltaic irrigation system", Applied Energy, Vol. 260, p. 114261, 2020.

[8] S. J. Seidel, N. Schütze, M. Fahle, J. C. Mailhol, and P. Ruelle, "Optimal irrigation scheduling, irrigation control and drip line layout to increase water productivity and profit in subsurface dripirrigated agriculture", Irrigation and Drainage, Vol. 64, No. 4, pp. 501-518, 2015.

[9] I. Yahyaoui, M. Chaabene, and F. Tadeo, "Evaluation of maximum power point tracking algorithm for off-grid photovoltaic pumping", Sustainable Cities and Society, Vol. 25, pp. 6573, 2016.

[10] H. Rezk and A. M. Eltamaly, "A comprehensive comparison of different MPPT techniques for photovoltaic systems", Solar Energy, Vol. 112, pp. 1-11, 2015.

[11] R. Kumar and B. Singh, "Single stage solar PV fed brushless DC Motor Driven Water Pump", IEEE Journal of Emerging and Selected Topics in Power Electronics, Vol. 5, No. 3, pp. 13771385, 2017.

[12] R. Kumar and B. Singh, "Solar PV powered BLDC Motor Drive for water pumping using CUK Converter", IET Electric Power Applications, Vol. 11, No. 2, pp. 222-232, 2017.

[13] B. Singh and R. Kumar, "Solar photovoltaic array fed water pump driven by brushless DC motor using Landsman converter", IET Renewable Power Generation, Vol. 10, No. 4, pp. 474-484, 2016.

[14] R. Kumar and B. Singh, "BLDC motor-driven solar PV array-fed water pumping system employing zeta converter", IEEE Transactions on Industry Applications, Vol. 52, No. 3, pp. 2315-2322, 2016.

[15] A. Lazizi, M. Kesraoui, and A. Chaib, "Fuzzy logic MPPT control for a solar PV module applied to water pumping", International Journal of Industrial Electronics and Drives, Vol. 3, No. 1, pp. 1-11, 2016.

[16] C. Jamroen, P. Komkum, C. Fongkerd, and W. Krongpha, "An intelligent irrigation scheduling system using low-cost wireless sensor network toward sustainable and Precision Agriculture", IEEE Access, Vol. 8, pp. 172756-172769, 2020.

[17] M. P. Picazo, J. Juárez, and D. G. Márquez, "Energy consumption optimization in irrigation networks supplied by a standalone direct pumping photovoltaic system", Sustainability, Vol. 10, No. 11, p. 4203, 2018.

[18] A. M. García, I. F. García, E. C. Poyato, P. M. Barrios, and J. A. R. Díaz, "Coupling irrigation scheduling with solar energy production in a Smart Irrigation Management System", Journal of Cleaner Production, Vol. 175, pp. 670-682, 2018.

[19] R. E. Kalman, "A new approach to linear filtering and prediction problems", Journal of Basic Engineering, Vol. 82, No. 1, pp. 35-45, 1960.

[20] S. Motahhir, A. Aoune, A. E. Ghzizal, S. Sebti, and A. Derouich, "Comparison between Kalman filter and incremental conductance algorithm for Optimizing Photovoltaic Energy", Renewables: Wind, Water, and Solar, Vol. 4, No. 1, 2017.

[21] O. Castillo, L. A. Angulo, J. R. Castro, and M. G. Valdez, "A comparative study of type-1 fuzzy logic systems, interval type-2 fuzzy logic 
systems and generalized type-2 fuzzy logic systems in control problems", Information Sciences, Vol. 354, pp. 257-274, 2016.

[22] N. Karami, N. Moubayed, and R. Outbib, "General Review and classification of different MPPT techniques", Renewable and Sustainable Energy Reviews, Vol. 68, pp. 1-18, 2017.

[23] S. Bana and R. P. Saini, "A mathematical modeling framework to evaluate the performance of single diode and double diode based SPV systems", Energy Reports, Vol. 2, pp. 171-187, 2016.

[24] A. Aoune, S. Motahhir, A. E. Ghzizal, S. Sebti, and A. Derouich, "Determination of the maximum power point in a photovoltaic panel using Kalman Filter on the environment PSIM", In: Proc. of International Conference on Information Technology for Organizations Development, pp. 1-4, 2016.

[25] J. Fadil, S. Soedibyo, and M. Ashari, "Novel of vertical axis wind turbine with variable swept area using Fuzzy Logic Controller", International Journal of Intelligent Engineering and Systems, Vol. 13, No. 3, pp. 256-267, 2020, doi: 10.22266/ijies2020.0630.24.

[26] N. K. A. Mefleh, S. Talozi, and K. A. Naser, "Assessment of treated wastewater reuse in drip irrigation under different pressure conditions", Water (Basel), Vol. 13, No. 8, p. 1033, 2021.

[27] S. Ozdemir, N. Altin, and I. Sefa, "Fuzzy logic based MPPT controller for high conversion ratio quadratic boost converter", International Journal of Hydrogen Energy, Vol. 42, No. 28, pp. 17748-17759, 2017.

[28] J. Fadil, S. Soedibyo, and M. Ashari, "Smart variable rotor of vertical axis wind turbine with faster cut-in speed and wide range extract power using artificial intelligent", International Journal of Intelligent Engineering and Systems, Vol. 13, No. 6, pp. 500-511, 2020, doi: 10.22266/ijies2020.1231.44.

[29] Z. Zarkov and L. Stoyanov, "Emulator of PV panels for laboratory studies", In: Proc. of $11^{\text {th }}$ Electrical Engineering Faculty Conference, pp. 1-5, 2019.

[30] R. Ayop and C. W. Tan, "A comprehensive review on photovoltaic emulator", Renewable and Sustainable Energy Reviews, Vol. 80, pp. 430-452, 2017.

[31] S. Suwito, M. Rivai, M. Ashari, and M. A. Mustaghfirin, "Simple and fast response photovoltaic panel emulator using transistor current source", In: Proc. of International Conference on Electrical and Information Technology, pp. 223-227, 2021. 